\title{
Nagy és kis felbontású képek használhatóságának összehasonlítása
}

\author{
Elek István
}

DOI: https://doi.org/10.30921/GK.71.2019.1.2

Abstract: In this article, we present a procedure that uses low resolution cameras to quickly define the boundaries of point clouds. Using the same procedure, we get almost identical results to high resolution images. In this article, the emphasis is not so much on the process presented, but on the fact that applying the process to images of low resolution cameras will result in the process being quicker. This result is therefore remarkable because the segmentation and clustering methods, when applied to high resolution images, are sometimes overwhelmingly slow. The approach described in this article attempts to provide a possible solution to this problem.

A cikkben bemutatunk egy eljárást, amely alacsony felbontású kamerák képét használva igen gyorsan képes pontfelhók határait megállapítani. Ugyanezt az eljárást alkalmazva nagy felbontású képekre majdnem teljesen azonos eredményt kapunk. A cikkben a hangsúly nem annyira a bemutatott eljáráson van, hanem azon a tényen, hogy az alacsony felbontású kamerák képeire alkalmazva az eljárást több nagyságrenddel gyorsabb lesz a folyamat. Ez az eredmény ezért figyelemre méltó, mert a szegmentáló, osztályozó eljárások a nagy felbontású képekre alkalmazva, néha nyomasztóan lassúak. A cikkben ismertetett megközelités erre a problémára próbál adni egy lehetséges megoldást.

Kulcsszavak: alacsony felbontású kamera, képfeldolgozás, alakfelismerés Keywords: low resolution cameras, image processing, shape recognition

\section{Bevezetés}

A technológiai fejlôdés eredményeként egyre nagyobb felbontású kamerák kerülnek kereskedelmi forgalomba. Az ûrtechnológia rohamos fejlốdése egyre jobb múholdképek készítését teszi lehetôvé. Az önvezetố gépkocsik fejlesztôii is egyre nagyobb felbontású kamerákkal szerelik fel a kísérleti jármúveket, így a kisebb felbontású képek készítésére alkalmas eszközök már csak fôként hobbicélokra használatosak.

Senki nem vizsgálja a kisebb felbontású kamerák lehetôségeit, mivel a nagy felbontásúak valóban egyre részletgazdagabbak. Ebben a cikkben arra próbáljuk felhívni a figyelmet, hogy vannak olyan múveletek, amikre akkor van szükség, ha nagyobb összefüggéseket (a képhez képest nagyobb méretû objektumokat) nagyon gyorsan akarunk detektálni.

Nagy felbontású képek esetében éppúgy szükséges lehet az osztályozás, szegmentálás, mint a kisebb felbontásúak esetében, de ilyenkor igen nagygyá válhat az eljárások futási ideje. Egyes esetekben (pl. hiperspektrális képek) nem is tudjuk felhasználni az összes csatornát az osztályozásra, mivel kivárhatatlanul sokáig tartana az osztályozó algoritmus futásideje. Ezért dimenziócsökkentést (főkomponens analízist) használnak az adatrendszer méretének drasztikus csökkentésére, ami persze hatalmas adatvesztés, még ha a fôkomponens-analízis esetében a lehetô legkisebb is az információveszteség. Az általunk felvetett megközelítés abból indul ki, hogy a nagyobb összefüggó területek, objektumok határainak megállapítására nem csak a nagy felbontású képeket lehet használni. Ha ezek a nagyobb szegmenshatárok megvannak, akkor már ezeken belül lehet, sốt kell is a nagy felbontású képekkel foglalkozni. Például az autonóm gépkocsi esetén egy ember, egy másik jármú, bármely, az úton lévố tárgy kontúrjainak felismerése elsôrendû feladat, amit igen gyorsan kell megvalósítani. Hasonlóan fontos egy KRESZ-tábla gyors felismerése, de a tábla alatt lévố felirat (pl. idôkorlátozás) elolvasása már nem annyira érzékeny az idôre, és így annak értelmezése már mehet a nagyobb felbontású képrôl. Csakhogy ebben az esetben már elegendô csak a tábla kisebb környezetét nézni, ami a nagy felbontású kép esetén sem kezelhetetlenül nagy adattömeg

A következőkben bemutatunk egy eljárást, amely kisebb felbontású kamerák képeinek használhatóságát demonstrálja, nem kompromisszumos megoldásként, hanem valós felhasználásra. Az eljárást szintetikus képeken fogjuk demonstrálni.

\section{Szintetikus képek elemzése}

Szintetikus képekre, pontfelhôkre fogjuk bemutatni a koncepciót, mert ezek a képek úgy lettek létrehozva, hogy világosan felismerhetők legyenek a súrúsödések, a csomópontok, a klaszterek. Vizuális interpretációval a másodperc tört része alatt felismerjük ezeknek a klasztereknek a meglétét, határait, vagyis nagyon gyorsan képesek vagyunk értelmezni a látott képet. $\mathrm{Az}$ értelmezés itt hangsúlyos szó, mert egy mozgó jármú esetében a kamerák által látott képek gyors értelmezése, az ott látott objektumok felismerése és azonosítása alapvetô feladat.

Generáljunk egy három csomópont körül, véletlenszerūen szóródó pontokból álló képet (1. ábra).

Amikor rápillantunk az ilyen képekre, a másodperc tört része alatt felismerjük ezeket a súrúsödési pontokat, mintegy azonnal észrevesszük azokat a területeket, amelyek a sûrûsödések alapján kijelölhetôk. Általános problémának mondhatók az effajta feladatok, amikor is csoportosítanunk kell a képek pixeleit (nem feltétlenül valamenynyit). Erre a célra a jól ismert klaszterezés és osztályozás nevú eljárások szolgálnak (Gonzalez-Woods 2018). Ezek futási ideje azonban általában nagy, ezért valós idejű, gyors csoportosításra 


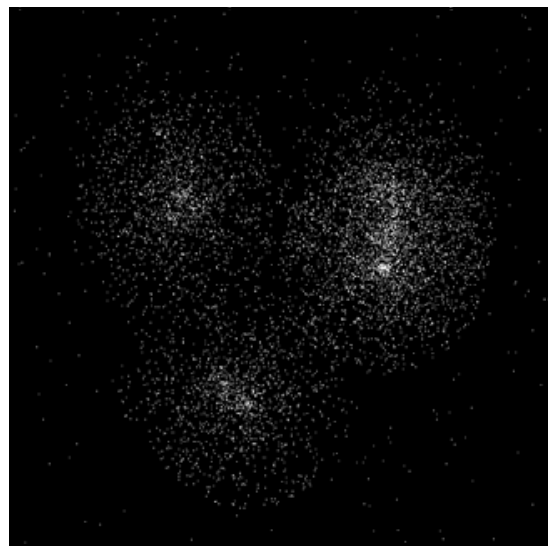

1. ábra. A generált kép, amelynek mérete $512 \times 512$ pixel, 24 bites, de csak két szint látunk rajta: fekete háttéren fehér pontszórást

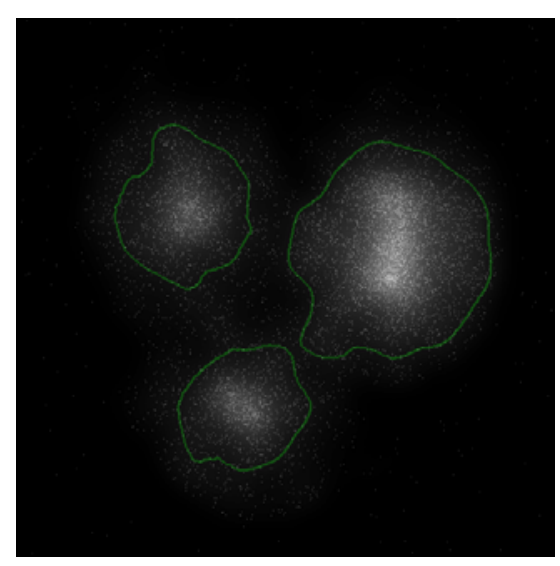

4. ábra. Az összerajzolt eredeti pontok, a pontfelhố és vektoros pontfelhôhatárok

kevéssé alkalmasak. Különösen igaz ez olyan alkalmazásokra, ahol fontos a rövid futási idô, mint pl. önvezetố gépkocsi kameraképeinek feldolgozása.

A látás fiziológiájáról felhalmozott ismeretek alapján tudható, hogy az emberi szem nem túl nagy felbontású eszköz, mégis az agyunk által értelmezett képek meglehetôsen jók, sok finom részletet vagyunk képesek felismerni, sôt ezek alapján úgy néz ki, mintha a szemünk egy nagy felbontású eszköz lenne. Ennek a jelenségnek az oka, hogy ezeket a kevéssé nagy felbontású képeket az agyunk feldolgozza, és a tudatunk már csak a feldolgozott képpel „találkozik". A látáspszichológia szakembereinek eredményei alapján tudjuk, hogy a szemünkben éldetektorok is múködnek. Nyolc különbözô irányú Gaborszúrố végzi az éldetektálást (Gregory 1973). Mint ismeretes, az éldetektálás az alakfelismerés egyik alapvető eljárása (Allen-Mills 2004). A szemünk az evolúció során meg kellett állapítsa a környezetében lévố objektumok kontúrjait, hiszen ez alapján kellett felismernie

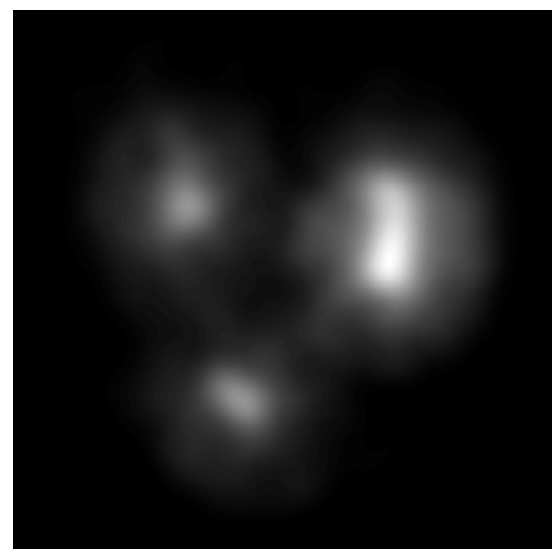

2. ábra. A simitással kapott felülvágott pontfelhố képe

az ellenséget, az azonos törzsbe tartozó másik embert, a családot és bármit, ami az élete során befolyásolta a boldogulását, a túlélését (Elek 2016). Abban egészen biztosak lehetünk, hogy sem az ember, sem az állatvilág egyetlen, látással is rendelkezô entitása nem alkalmaz a látása során klaszterező, osztályozó eljárásokat a pixelek összetartozásának felismerésére. Márpedig a képek értelmezése lehetetlen anélkül, hogy elszakadjunk a képek pixeles logikájától. Élek és csoportok megállapítása nélkül lehetetlen bármiféle értelmezett képet előállítani. Valamilyen vektorizált, csomópontokból felépített alakzatot tudunk csak értelmezni a nyers pixelek helyett.

A következőkben bemutatunk egy eljáráscsomagot, amely éldetektálásra alapozva megállapítja az 1. ábrán lévô pontfelhő határait és ezt mint vektoros adatot előállítja. Az eljárás a következô lépésekbôl áll: Erôs simító szúrés $\rightarrow$ küszöbölés $\rightarrow$ éldetektálás $\rightarrow$ vektorizálás.

Az egyes szúrési eljárások múködésének bemutatásától itt eltekintünk, mivel részletesen tanulmányozhatók az (Allen-Mills 2004, Elek 2010 , Gonzalez-Woods 2018,) munkákban. Az eljáráscsomag múködése vázlatosan a következő:

1. A simító szúréssel összemossuk a pixelek individuális jellegét, mintegy felhôvé alakítjuk a képet (2. ábra). Az eljárás futási ideje 12000 milliszekundum az 1. ábrán látható méretû képre.

2. A küszöböléssel, és éldetektálással előállítunk egy kétállapotú képet.

3. A küszöbértéket az intenzitásértékek eloszlásából kapjuk meg.

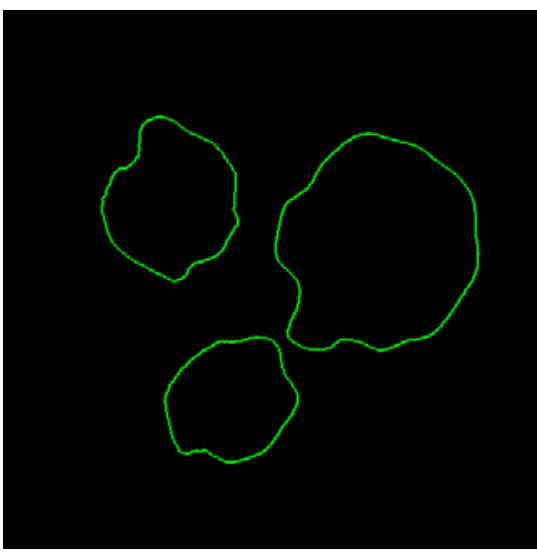

3. ábra. A pontfelhô vektoros határai a nagy felbontású képen

4. Végül megállapíthatjuk a pontfelhôk határait. Az eljárás futási ideje 25 milliszekundum.

Az 1.-4. folyamat eredménye látható a 3. ábrán. A kép azért kétállapotú, mert az intenzitás mindenhol 0 a határok kivételével. A határokon viszont az intenzitásérték 255. Egy ilyen képre a vektorizálás triviális feladat (Cormen et al. 2009).

Hasonlítsuk össze a kiindulási képet az eredménnyel (4. ábra). Ebből látható, hogy a pontfelhô határait az eljárás helyesen határozta meg. (Ugyanakkor nyilvánvaló az is, hogy többféle határ is megállapítható, attól függően, hogy milyen paramétert adunk meg az eljárás számára. A kis és nagy felbontású képekre mindig ugyanazt a paramétert fogjuk használni a korrekt összehasonlíthatóság kedvéért.).

A pontfelhôk határainak megállapítása általános probléma a képfeldolgozásban és egyes térinformatikai feladatokban (Sidiropoulos-Lakakis 2016, Almqvist et al. 2017, Mineo-PierceSumman 2019), de ezekre a jelen eljárással kapcsolatban nem térünk ki, hiszen célunk annak megmutatása, hogy a kis felbontású képek is jól használhatók egyes speciális problémák megoldására.

Az eddig bemutatott eljáráscsomag a képfeldolgozásban jól ismert elemekbôl áll. A vektoros kép előállítása hozzávetőleg 12 másodperc, amely a simító szúrés miatt ennyi. A vektoros pontfelhôhatárok előállításának ideje ehhez képest elhanyagolható (25 ms). Vagyis, ebbôl következôen a simított pontfelhố elôállításának idejét kellene drasztikusan csökkenteni, ha a gyakorlatban is használható gyors 
eljárást szeretnénk kapni. Ehhez gondoljuk végig a kamera képének előállítása mögött meghúzódó fizikát.

\section{A fényérzékeny lapkák képalkotása}

A fotoelektromos hatás olyankor jön létre, amikor egy a küszöbszintnél nagyobb frekvenciájú elektromágneses sugárzás, mint például fény, által egy anyag (többnyire fém) felszínén lévố elektron kilökôdik. A határfrekvencia alatt nem történik elektronkibocsátás, mert a foton nem tud elég energiát biztosítani ahhoz, hogy az elektronok kilépjenek az atomos kötésből. A fénysugár fotonjai a hullámhossztól függó nagyságú energiával rendelkeznek. Ha növeljük a fénysugárzás intenzitását, az nem változtatja meg a fénysugarat alkotó fotonok energiáját, de a kibocsátott elektronok számát igen, így a jelenség alkalmas felületek leképezésére. Ezen a jelenségen alapul a kamerák félvezetô lapkáinak múködése (5. ábra).

A fentiekból látható, hogy egy kép méretét a fényérzékeny lapka felbontóképessége határozza meg. Ahány fényérzékeny elemi cellát integrálunk egy

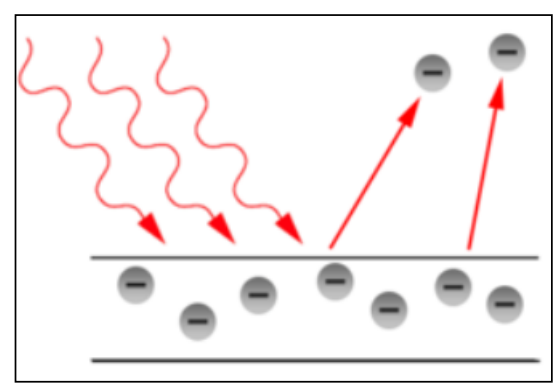

5. ábra. A felületre belépố fény intenzitásától függố töltésszám mérésével a belépố fény intenzitása mérhetố, vagyis a felület leképezhetô (Wikipedia: Fényelektromos jelenség)

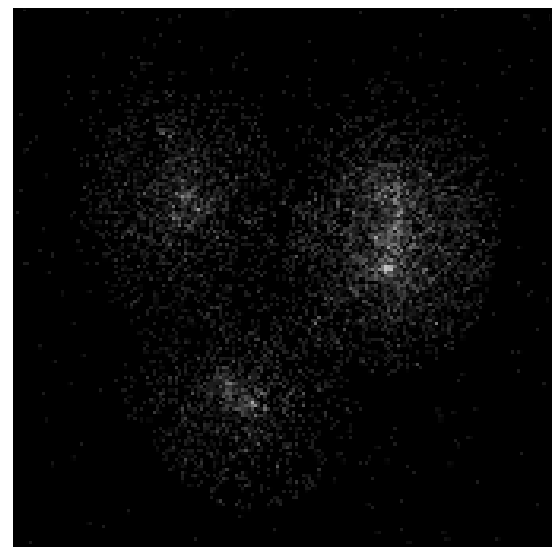

6. ábra. A kis felbontású kép $(170 \times 170$ pixel $)$ lapkára, annyi pixeles képet fogunk kapni. Az is látható viszont, hogy minden lapka elemi cellája átlagolja a kilépó elektronokat, azaz a fény intenzitását, és ennek megfelelố töltésszámot produkál. Így tehát egy nagy felbontású kamera kisebb területre átlagol, mint egy kisebb felbontású.

A digitális szû́rôk elméletébôl tudjuk, hogy az átlagolás simítást eredményez, mivel a simítás paramétereiért felelős kernel és a kép konvolúciója által jön létre a simított kép (AllenMills 2004, Elek 2010, Gonzalez-Woods 2018). (Azt most ne feszegessük, hogy ez a bizonyos átlagolás pontosan mit is jelent. Egyelőre tegyük fel, hogy a kernelben egy Gauss-függvény értékei vannak, de ha csupa 1-es van benne, az is elfogadható). Ebbôl következôen, ha a simítást nem egy nagy felbontású kép konvolúciós szúrésével végezzük, hanem egy kisebb felbontású kamera képét használjuk, amely már eleve simítottabb képet ad, hiszen a fizika elvégezte helyettünk a konvolúciót, akkor a legidôigényesebb folyamatot sikerül kiküszöbölnünk a vektorizálási procedúrából.

\section{Kis és nagy felbontású képek feldolgozásának összehasonlítása}

A következókben vizsgáljuk meg, hogy egy lényegesen kisebb felbontású kép feldolgozásából származó vektoros határok mennyire térnek el a nagy felbontású kamera képének feldolgozásából származó határoktól. Az eredeti kép méretének harmadával rendelkezô felbontású képre $(170 \times 170$ pixel) futtassuk le a fenti eljárásokat. A 6 . ábrán

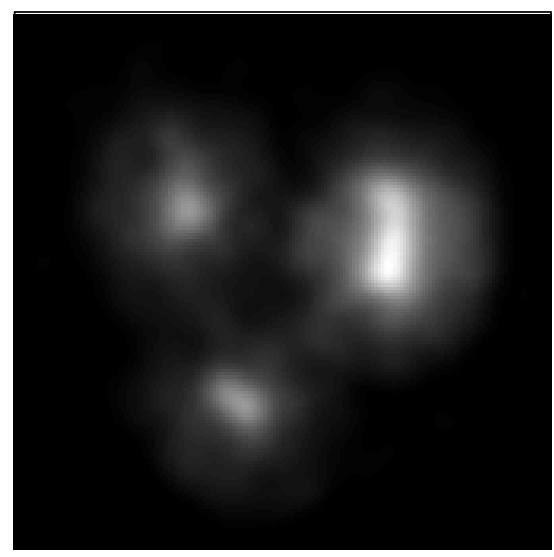

7. ábra. A kis felbontású simított kép a kis felbontású kép látható a feldolgozás elôtt.

A kis felbontású képet vessük alá simító szúrésnek, ugyanazzal a felsố határfrekvenciával, mint a nagy felbontású kép esetén tettük. A 7. ábrán a simított kép felhôje látható.

Végezzük el az éldetektálást, a küszöbölést és a vektorizálást, ugyanazokkal a paraméterekkel, mint a nagy felbontású kép esetén tettük. A 8. ábrán a pontfelhố vektoros határai láthatók.

Vizsgáljuk meg, hogy a kis felbontású képre kapott felhôkontúrokat megfelelốnek találjuk-e? Ha megtekintjük a 9. ábrát, akkor megállapítható, hogy a pontfelhôkontúrok megfelelnek az elvárásainknak. Megfelelés alatt itt azt értjük, hogy ha szemrevételezéssel állapítottuk volna meg a határokat, az eredmény annak megfelelő.

Érdekes feladat a kétféle eredmény összehasonlítása. Mivel nem áll rendelkezésünkre egy olyan etalon, amelyhez tudnánk hasonlítani az eredményt, ezért kézenfekvô, hogy a kétféle eredményt hasonlítsuk össze, vagyis a nagy és kis felbontású képek feldolgozásából kapott kontúrokat vessük össze. Amint látható, a két eredmény igen közel áll egymáshoz (10. ábra), noha természetesen nem azonosak. Ami viszont figyelemre méltó az a futásidôk különbsége. Míg az $512 \times 512$ pixeles képre a feldolgozási idô 12000 milliszekundum, addig a $170 \times 170$ pixeles képre ez mindössze 167 milliszekundum, vagyis a sebességnövekedés több mint hetvenszeres.

A vizuális összehasonlítás (10. ábra) alapján a két kép rendkívül hasonló. Egymás mellé állítva a két ábrát minimális eltérés fedezhetô fel a két kép

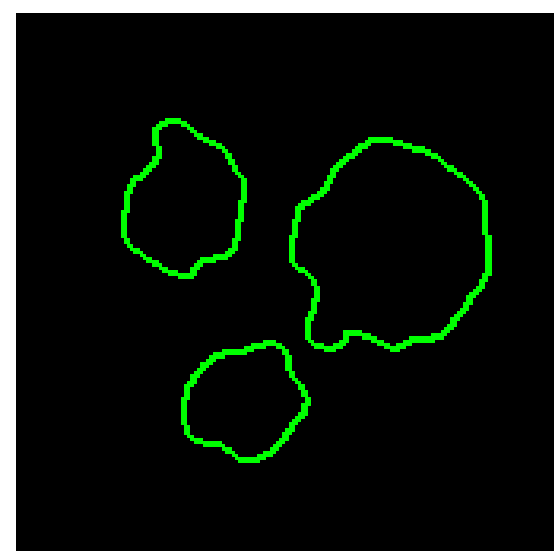

8. ábra. A kis felbontású kép pontfelhôinek vektoros határai 


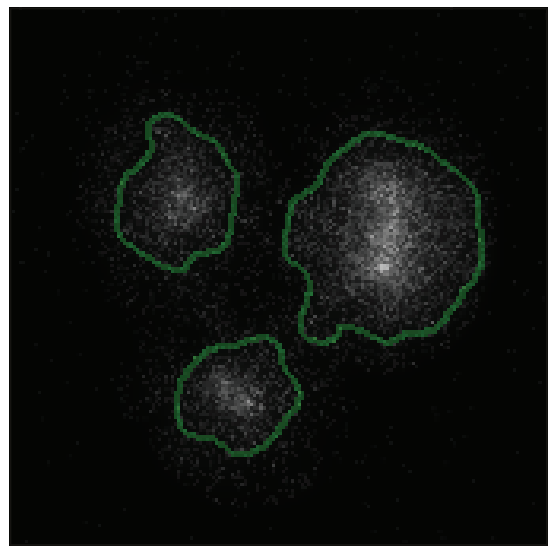

9. ábra. A kis felbontású kép, a felhố és a feldolgozás eredménye

között. A vizuálisnál precízebbnek ható numerikus összehasonlítás is hasonló eredményt ad (a kétféle kontúr korrelációs együtthatója 0,997), de a vizuális hasonlóságot jelen esetben lényegesebbnek tartom. Igen szoros korreláció esetén sem lennénk elégedettek, ha a vizuális összehasonlítás nem adna kielégítő eredményt.

Hasonlítsuk össze egy más paraméterú (több kiesố pontot megengedô) futtatás eredményeit, de most úgy, hogy a kis és nagy felbontású képek feldolgozásából származó kontúrokat egymásra rajzoljuk (11.ábra). Amint az ábráról látható a vékony görbe (a nagy felbontású képrôl származó kontúr) és a vastag (a kis felbontású képrôl származó kontúr) teljesen egymáson fut.

\section{Összegzés}

Végkövetkeztetésként kimondható, hogy a kisebb felbontású kamerák alkalmasak arra, hogy a nagy felbontású képeken található nagyobb objektumok határait viszonylag gyorsan megállapíthassuk, lényegesen gyorsabban, mintha a nagy felbontású képeken tennénk ugyanezt. Ez persze nem jelenti azt, hogy ne volna érdemes nagy felbontású kamerákat alkalmazni. Futásidőérzékeny esetekben, mint amilyen az autonómvezetô-probléma, érdemesnek látszik különbözô felbontású kamerák együttes alkalmazása. A nagyobb objektumok határainak megállapítása után természetesen a finomabb részletek megállapításához továbbra is a nagy felbontású képeket érdemes alkalmazni.

Erre számtalan példa van az élóvilágban. A nagyobb összefüggések megállapítása után a lények képesek egy-egy
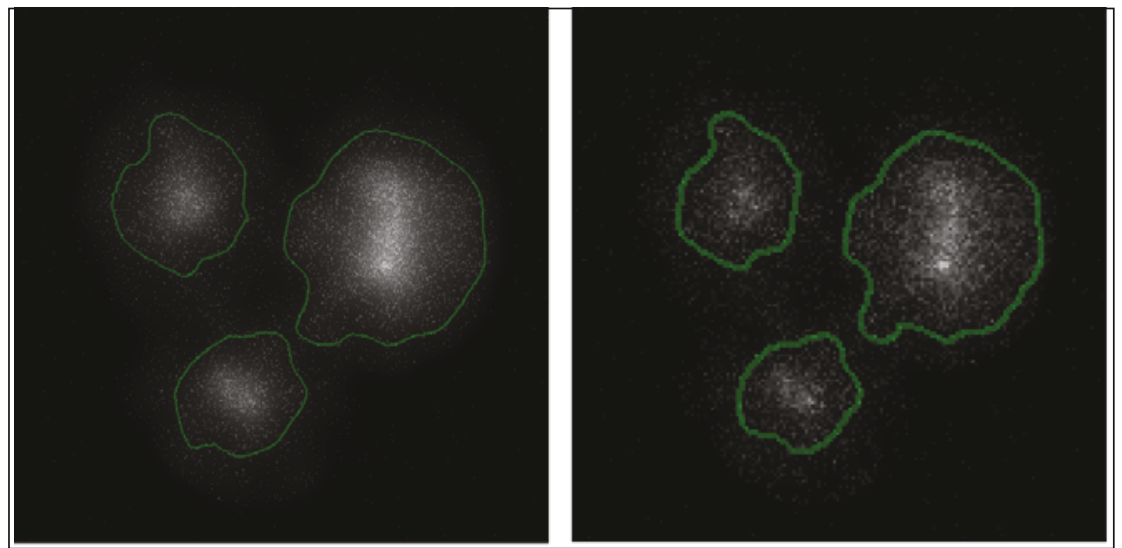

10. ábra. Az ábra bal oldali része a nagyobb, míg a jobb oldali a kisebb felbontású képet és a feldolgozások eredményeit mutatja

részletre fókuszálni, sôt egyes esetekben (pl. sasok esetén) zoomolásra képes a szemük. Még zoomra képtelen szem esetén is, mint amilyen az emberi szem, ismerjük az egy-egy részletre koncentrálás jelenségét, amikor a nagyvonalú kiértékelést követôen egy-egy részlet megfigyelésével (és a többi részlet figyelmen kívül hagyásával) a részletek megállapítása a feladat.

Akár autonóm gépkocsivezérlésről, akár ûrfelvételek feldolgozásáról van szó, úgy tûnik, hogy a kisebb felbontású kamerákat sem kell mellőzni, mivel a különböző felbontású képek okos kombinálásával jelentősen felgyorsíthatók egyes feldolgozási folyamatok.

\section{Köszönetnyilvánítás}

A munkákat egy kutatás-fejlesztési pályázat finanszírozta: EFOP-3.6.3-VEKOP-16-2017-00001: Tehetséggondozás és kutatói utánpótlás fejlesztése autonóm jármúirányítási technológiák területén. A projekt a magyar állam és az Európai Unió támogatásával, az Európai Szociális Alap társfinanszírozásával valósult meg.

\section{Irodalomjegyzék}

Allen, R. - Mills, D. 2004. Signal Analysis, Time, Frequency, Scale, and Structure. Wiley, IEEE

Almqvist, H. - Magnusson, M. - Kucner, T - Lilienthal, A. 2017. Learning to detect misaligned point clouds, Wiley, DOI: 10.1002/rob. 21768

Cormen, T. - Leiserson, C. - Rivest, R. Stein, C. 2009. Introduction to Algorithms, 3rd Edition (The MIT Press), ISBN-13: 978-0262033848

Elek, I. 2010. Adatbázisok, térképek, információs rendszerek, ELTE Eötvös Kiadó, ISBN 9789633120392

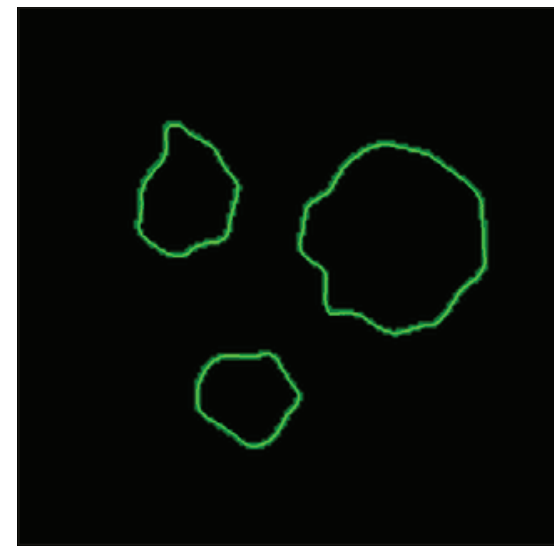

11. ábra. A kis és nagy felbontású képekből származó kontúrok összehasonlítása a két eredmény egymásra rajzolásával

Elek, I. 2016. Emergence of intelligence, NOVA Science publishers, New York, , ISBN 978-1-53613-545-9

Gonzalez, R. - Woods, R. 2018. Digital Image Processing, Pearson

Gregory, R. 1973. Az értelmes szem. Gondolat Kiadó

https://hu.wikipedia.org/wiki/Fényelek tromos jelenség, utolsó elérés: 2019. 02 06.

Mineo, C. - Pierce, S. - Summan, R. 2019. Novel algorithms for $3 D$ surface point cloud boundary detection and edge reconstruction, Journal of Computational Design and Engineering, Volume 6, Issue 1

Sidiropoulos, A. - Lakakis, K. 2016. Edge Points Detection in Unorganized Point Clouds, International Journal of Constructive Research in Civil Engineering (IJCRCE) Volume 2, Issue 3, DOI: https://doi.org/ 10.20431/2454-8693.0203002

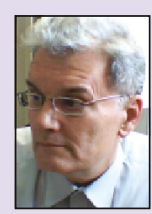

\section{Dr. Elek \\ István \\ egyetemi \\ docens}

ELTE Térképtudományi és Geoinformatikai Tanszék elek@map.elte.hu 